Original Paper http://ajol.info/index.php/ijbcs http://indexmedicus.afro.who.int

\title{
Effect of local hot smoking on proximate composition, lipid oxidation, fatty acid profile and minerals content of Chrysichthys nigrodigitatus from Lake Maga in Cameroon
}

\author{
Noël TENYANG ${ }^{1 *}$, Roger PONKA ${ }^{2}$ and Hilaire Macaire WOMENI ${ }^{3}$ \\ ${ }^{1}$ University of Maroua, Faculty of Science, Department of Biological Sciences, P.O. Box 814 Maroua, \\ Cameroon. \\ ${ }^{2}$ University of Maroua, National Advanced School of Engineering of Maroua, Department of Agriculture, \\ Livestock and By-Products, P.O. Box 46, Maroua, Cameroon. \\ ${ }^{3}$ University of Dschang, Faculty of Science, Department of Biochemistry, P.O. Box 67 Dschang, Cameroon. \\ *Corresponding author; E-mail: tenoel2003@yahoo.fr
}

\begin{abstract}
Fish with higher nutrient qualities can be used to solve malnutrition problems in Africa. So the aim of this study was to evaluate the effect of local smoking on proximate composition and lipid oxidation of Chrysichthys nigrodigitatus collected in Cameroon. The proximate composition was assessed using standard methods while lipid quality assessment was based on the determination of biochemical indexes. A change on fatty acid composition was evaluated by gas chromatography while minerals composition was evaluated by spectrophotometer. On nutritional point of view, raw fish have high protein, lipid and ash contents $(51.87,37.48$ and $8.55 \mathrm{~g} / 100 \mathrm{~g}$ dry weight respectively). Unsaturated fatty acid may be up to $57 \%$ of the total fatty acids. Raw C. nigrodigitatus contain reasonable amount of minerals. Smoking process increased ash and lipid content while proteins and moisture contents are reduced in these fish. The iodine value of $C$. nigrodigitatus was reduced while acid, peroxide and TOTOX values increased during smoking. The marked decrease of polyunsaturated fatty acids was noted during processing. Mineral contents were affected by smoking process. Calcium, magnesium, potassium, sodium, manganese and iron contents increased significantly. In conclusion, hot smoking enhances nutrients content of $C$. nigrodigitatus while significant reduction in lipid quality was recorded.
\end{abstract}

(C) 2020 International Formulae Group. All rights reserved.

Keywords: Chrysichthys nigrodigitatus, smoking process, nutritional value, lipid oxidation, mineral contents.

\section{Effet du fumage traditionnel sur la composition chimique, l'état d'oxydation des lipides, la composition en acide gras et la teneur en minéraux de Chrysichthys nigrodigitatus du Lac Maga au Cameroun}

\section{RÉSUMÉ}

Le Poisson est l'une des sources d'éléments nutritifs de qualité pouvant contribuer à prévenir la malnutrition en Afrique. Ce travail s'est donné pour objectif d'évaluer l'effet du fumage traditionnel sur la composition chimique et l'état d'oxydation des lipides de Chrysichthys nigrodigitatus provenant du Lac Maga au Cameroun. Les méthodes standards ont été utilisées pour la détermination de la composition chimique, la 
mesure de l'état d'oxydation des lipides par des indices chimiques, la composition en acides gras par chromatographie en phase gazeuse et les minéraux par spectrophotométrie. Du point de vue nutritionnel, ce poisson frais contient respectivement 51,$87 ; 37,48$ and $8,55 \mathrm{~g} / 100 \mathrm{~g}$ de matière sèches de protéines, lipides et cendres. Il contient également $57 \%$ d'acides gras insaturés et une quantité raisonnable de minéraux. Le traitement de fumage provoque une augmentation de la teneur en cendres et en lipides. Par contre la teneur en eau et en protéines diminuent. L'indice d'iode baisse tandis que les indices d'acide, de peroxyde et de TBARs augmentent. Une diminution du taux d'acides gras polyinsaturés est observée. Les minéraux sont également affectés au cours du fumage. Le traitement de fumage améliore la teneur en nutriments de $C$. nigrodigitatus, par contre réduit la qualité lipidique de celui-ci.

(C) 2020 International Formulae Group. All rights reserved.

Mots clés: Chrysichthys nigrodigitatus, fumage, valeur nutritionnelle, oxydation des lipides, teneur en minéraux.

\section{INTRODUCTION}

Malnutrition in developing countries is considered as a major public health problem (FAO, 2010). It is a risk for illness and death for many persons particularly children and pregnant women. Malnutrition largely caused by poor food quality, insufficient food intake, inadequate micronutrients intakes and sometimes infectious diseases (Bhandari and Banjara, 2014). In food security, fish has an important role. It is an important food for over 400 million Africans, contributing essential proteins, minerals and micronutrients to the diet for Africans. In 21 African countries, fish supply over 25 percent of animal protein (Tocon and Metian, 2009). In rural and urban areas of Cameroon, fish can be used to prevent malnutrition and improve food security. It contains significant quantity of essential amino acids like lysine, which is very low in cereals. Fish has gained attention because of high content of polyunsaturated fatty acids. It is a virtual rich source of omega-3 long chain polyunsaturated fatty acid. Eicosapentaenoic acid (EPA) and docosahexanoic acid (DHA) have beneficial effects on certain diseases such as, cardiovascular diseases, colon cancer, coronary heart disease, and prostate. They also support brain development and function besides mental health. n-3 polyunsaturated fatty acids might favourably improve lipid profile (Njinkoué et al., 2017).

Fish also contains many fat soluble vitamins which are essential for human body
(Al-Jedah and Robinson, 2001). Macro and essential trace elements such as iron, zinc, Fe present in fish are important in human nutrition (Alas et al., 2014). Deficiency in minerals, however, can have a major impact on health such as anaemia and osteoporosis that commonly occur in both developed and developing countries. The accurate determination of these elements is therefore important in nutrition studies, particularly because meat, as a biological material, exhibits natural variations in the amounts of nutrients contained.

To preserve the quality of fish and increase their shelf life, smoking and drying have long worldwide used. These processes reduce moisture content of fish and reduce the growth of spoilage microorganisms. The method of drying depends on the fish species used and the interest of consumers. Fish muscles undergo a number of changes which modify their structural and functional properties during smoking. Smoking could have varying effects on their nutrients. The degrees of changes are linked to the fish species, the presence or absence of activators and inhibitors (Goulas and Kontominas, 2005).

Chrysichthys nigrodigitatus is a common fish in Lake Maga (Far North region, Cameroon). It is usually sold as a raw product. The application of smoking for the extension of the shelf-life is a process of interest.

Several studies have reported the nutritive value and effect of processing on fish 
species in some countries. These included: Biochemical composition of some marine fish species of Ghana (Obodai et al., 2009), proximate composition, fatty acid and mineral contents of four freshwater fish from Lake Maga in Far North region of Cameroon (Tenyang et al., 2016), the changes of fatty acid composition in sun dried, oven dried and frozen hake (Merluccius merliccius) and sardinella (Sardinella aurita) (Khaoula et al., 2013), the influence of traditional drying and smoke drying on the quality of three fish species (Tilapia niloticus, Silurus glanis and Aurius parkii) from Lake Lagdo, Cameroon (Ali et al. 2011), the influence of smoking method on quality of traditional smoked Bonga shad (Ethnalosa frimbriata) fish from Lagos State, Nigeria (Adeyeye et al., 2015), the effect of boiling and smoking on proximate composition and oil quality of commercially important freshwater fish (Chrysichthys nigrodigitatus) from Nkam River in Littoral Region of Cameroon (Djopnang et al., 2018).

The effect of smoking process on the proximate composition, lipid oxidation, fatty acids profile and mineral content of Chrysichthys nigrodigitatus has not been studied extensively with no literature available on Chrysichthys nigrodigitatus from Lake Maga, Cameroon. The aim of this work was, thus, to evaluate the effect of local smoking process on proximate composition, lipid stability, fatty acid profile and mineral content of Chrysichthys nigrodigitatus from Lake Maga in Far North region of Cameroon.

\section{MATERIALS AND METHODS Samples}

Chrysichthys nigrodigitatus chosen for this study are the commonly fish consumed in the Far-North region of Cameroon. A total of 30 fresh raw samples were bought from Maga fish market in the Far North region of Cameroon. The average weight of each fish was $200 \pm 15 \mathrm{~g}$ with lengths ranging from 22 to $29 \mathrm{~cm}$. Once collected, they were immediately transported to the laboratory in ice boxes for analyses.

\section{Smoking}

The traditional heat smoking of fish was subjected to the combined treatments of drying, smoking and heat. During the process, the fresh raw fish were spread out on smoking trays after washing without salting. The trays were then placed on the fired wood oven at temperatures greater than $70{ }^{\circ} \mathrm{C}$. This process took 6 hours to obtain a dried smoked product. The raw and smoke-dried fish were allowed to cool at room temperature, then ground in an electric grinder (Panasonic, Kyoto, Japan) and stored at $4{ }^{\circ} \mathrm{C}$ for further analysis.

\section{Lipid extraction}

After smoking, oil was extracted from raw and smoking fish by the method described by Bligh and Dyer (1959). About $80 \mathrm{~g}$ of fish were introduced in a grinding machine (Panasonic, Kyoto, Japan) to which $100 \mathrm{~mL}$ of chloroform and $200 \mathrm{~mL}$ of methanol were subsequently added. The mixture was grinded for $3 \mathrm{~min}$; followed by the addition of $100 \mathrm{~mL}$ of chloroform and $100 \mathrm{~mL}$ of distilled water. The mixture was again grinded for $1 \mathrm{~min}$, and filtered. The final extraction was ensured by the addition of chloroform, in order to respect the following proportions: 2:2:1.8 for chloroform, methanol and distilled water respectively. After separating the different phases in a funnel, the organic phase was collected and dried using sodium anhydrous. The organic solvent was then, eliminated by evaporation on a rotator evaporator at $45{ }^{\circ} \mathrm{C}$ under reduced pressure. The extracted oil was stored at $4{ }^{\circ} \mathrm{C}$ for further analysis.

\section{Analytical methods \\ Proximate analysis of fish}

Moisture, fat, ash and protein in the fish samples were determined using standard analytical methods described by AOAC procedures (AOAC, 1990). Moisture content was determined by drying fish in oven at 103 
${ }^{\circ} \mathrm{C}$ until a constant weight was achieved according to the AOAC procedures 925.40 (AOAC, 1990). Ash content was determined by incineration fish at $550{ }^{\circ} \mathrm{C}$ according to the AOAC procedures 942.05 (AOAC, 1990). Nitrogen $(\mathrm{N})$ content was determined using micro-Kjeldahl method, according to AOAC procedures 984.13 (AOAC, 1990), the protein content was calculated as $\mathrm{N} \times 6.25$. Lipid content was determined using Soxhlet apparatus with hexane, following AOAC 963.15 methodology (AOAC, 1990). All samples were analysed in triplicate.

\section{Effect of treatment on lipid oxidation parameters}

\section{Measurement of free fatty acid (FFA)}

Free fatty acid (FFA) content was determined according to the method of AFNOR (1981). The fish oil sample (1g) was dissolved in $100 \mathrm{~mL}$ of ethanol and some drops of phenolphthalein were added as an indicator and swirled vigorously. The mixture was then titrated with potassium hydroxide $(0.1 \mathrm{M})$. The FFA was expressed as \% oleic acid.

\section{Iodine Value}

The iodine value (IV) of fish oil samples was determined using the wijs method, as described in the AOAC official method 993.20 (O'Keefe and Pike, 2010). The IV was expressed as $\mathrm{g} \mathrm{I}_{2} / 100 \mathrm{~g}$ of sample.

\section{Peroxide value}

The peroxide value was conducted by referring to the IDF standard method, 74A: 1991 (Santha and Decker, 1994). fish oil samples (0.0101-0.025 g) were mixed in a disposable glass tube with $9.8 \mathrm{ml}$ chloroformmethanol $(7: 3 \mathrm{v} / \mathrm{v})$ on a vortex mixer for 2-4 $\mathrm{s}$. Ammonium thiocyanate solution 30\% (50 $\mu \mathrm{l})$ was added and the sample was mixed on a vortex mixer for $2-4 \mathrm{~s}$. Then, $50 \mu \mathrm{l}$ iron II solution was added to the sample and mixed using a vortex mixer for 2-4 s. after $5 \mathrm{~min}$ incubation at room temperature, the absorbance of the sample was determined at $500 \mathrm{~nm}$ against a blank that contained all the reagents except the sample using a spectrophotometer (Perkin Elmer, Norwalk CT, USA). The entire procedure was conducted in subdued light and completed within $10 \mathrm{~min}$. To construct a standard curve of Fe (III) concentration vs absorbance, a serial of dilutions of standard solution of iron (III) chloride was prepared and treated exactly as before, except that standard was added instead of the sample, then concentration vs absorbance was plotted. The peroxide value, expressed as milliequivalents of $\mathrm{O}_{2} / \mathrm{kg}$ sample, was calculated using the following formula:

\section{$(A s-A b) \times m$ \\ Peroxide value $=$ \\ $55.84 \times \mathrm{m}_{0} \times 2$}

Where As= absorbance of the sample; $\mathrm{Ab}=$ absorbance of the blank; $\mathrm{m}=$ slope, obtained from the calibration curve (in this experiment 38.40); $\mathrm{m}_{0}=$ mass in grams of the sample; 55.84= atomic weight of iron.

\section{p-anisidine value}

Anisidine value was determined by the standard AOCS Cd 18-90 «p-anisidine value » using a Perkin Elmer UV-Visible Spectrophotometer (Norwalk CT, USA). In accordance with the method, $0.5-1 \mathrm{~g}$ of fish oil sample was weighed into a $25 \mathrm{~mL}$ volumetric flask. The oil sample was dissolved and diluted to $25 \mathrm{~mL}$ of volume with isooctane. Then the absorbance of the solution $\left(\mathrm{A}_{\mathrm{b}}\right)$ was measured in a cuvette at $350 \mathrm{~nm}$ with the spectrophotometer, using the reference cuvette filled with isooctane solvent as a blank. After the measurement of absorbance, $5 \mathrm{ml}$ of this solution and $5 \mathrm{ml}$ of isooctane were taken into two different tests tubes and $1 \mathrm{ml}$ of $0.25 \%$ acetic acid solution of $p$-anisidine was added and the mixtures were mixed using a vortex. After exactly 10 minutes of incubation at room temperature, the absorbance $\left(\mathrm{A}_{\mathrm{s}}\right)$ of the solution containing sample was read at $350 \mathrm{~nm}$, using the second solution as blank. $p$-anisidine value was calculated as followed: 


\section{$25\left(1.2 A_{s}-A_{b}\right)$}

\section{$\mathrm{p}-\mathrm{An}$ value $=$}

\section{m}

Where, $A_{s}$ is the absorbance of test solution after reaction with the $p$-anisidine reagent; $A_{b}$ is the absorbance of the fat solution; $m$ is the sample weight.

\section{TOTOX value}

Total oxidation (TOTOX) values of oils samples were determined based on the obtained peroxide and $p$-Anisidine values using the equation TOTOX $=2 \mathrm{PV}+\mathrm{AV}$ according to Shahidi and Wanasundara (2008).

\section{Fatty acid composition of fish oil}

Oil extracted from the powdered fish was used for the determination of fatty acid profile. The lipids were transmethylated using $\mathrm{NaOH} / \mathrm{MeOH}$ followed by $\mathrm{BF}_{3} / \mathrm{MeOH}$ according to the method described by Metcafe et al. (1996). The Fatty acids methyl esters (FAMEs) were analysed on a Hewlett Packard 5880 gas chromatography (GC) equipped with a Flame ionisation Detector. The esters were separated on a $50 \mathrm{~m} \mathrm{x} 0 . .20 \mathrm{~mm}$ id Wall-coated open tubular fused silicia capillary columm coasted with Carbowax $20 \mathrm{M}$. Columm injector and detector temperature were 200 and $300{ }^{\circ} \mathrm{C}$, respectively. The carrier gas was helium and the split ratio was 100/1. Identification and quantification of fatty acid were performed by comparison of their peak with the relevant peak areas of the corresponding standard fatty acids. Each fatty acid was then expressed as a percentage of the total fatty acids quantified. All the experiments were carried out in triplicate.

\section{Mineral determination of fish}

Mineral content determination of fish was done by ashing at $550{ }^{\circ} \mathrm{C}$ and the ash boiled with $10 \mathrm{~mL}$ of $20 \% \mathrm{HCl}$ in a beaker and then filtered into a $100 \mathrm{~mL}$ standard flask. Calcium $(\mathrm{Ca})$, magnesium $(\mathrm{Mg})$, sodium $(\mathrm{Na})$, potassium $(\mathrm{K})$, iron $(\mathrm{Fe})$, zinc $(\mathrm{Zn})$, copper $(\mathrm{Cu})$ and manganese $(\mathrm{Mn})$ were determined by atomic absorption spectrometer (Varian 220FS
Spectr AA, Les Ulis, France). Phosphorus (P) was determined calorimetrically using the vanado molybdate, according to AOAC procedure 965.17 (AOAC, 1999). Reference sample from parts of the daily routine in the laboratory was used for quality control. Certified reference material 1570a was purchased from the National Institute of Standard and Technology (Gaithersburg, USA). After initial standardisation of techniques during a pilot study, the samples were treated similarly. Mineral contents of the samples were determined from calibration curves of standards minerals. All samples were analysed in triplicate.

\section{Statistical analysis}

The results were calculated and expressed as Mean \pm standard Deviation. All results were submitted of variance (ANOVA) at $0.05 \%$ probability level. The Duncan test was used to compare the means using Statistical Package of Social Science (SPSS 16.0 version).

\section{RESULTS}

\section{Effect of smoking on proximate composition of $C$. nigrodigitatus}

The proximate composition of the raw and smoked Chrysichthys nigrodigitatus is presented in Table 1. As shown in this Table, differences in moisture contents between raw and smoked fish were found to be significant. The moisture content of raw fish was $72.62 \%$ higher than that of smoked fish sample (18.53\%). Raw Chrysichthys nigrodigitatus had $8.55 \%$ of ash content. After smoking, this value increase significantly $(\mathrm{P}<0.05)$. Lipid content was observed to be significantly different $(\mathrm{P}<0.05)$ between raw and smoked $C$. nigrodigitatus (Table 1), it could be noticed that lipid content increase during smoking. The result of protein content of raw $C$. nigrodigitatus obtained in this study was $51.87 \%$. This value decreased significantly during processing and smoked fish had $44.60 \%$ of protein content. 


\section{Effect of smoking on oil parameters quality of $C$. nigrodigitatus}

Table 2 shows the acid, iodine, peroxide, $p$-anisidine and TOTOX values of raw and smoked $C$. nigrodigitatus from Lake Maga in Far North region of Cameroon. The acid value measures the amount of carboxylic acid groups in free fatty acids. Free fatty acid (FFA) is considered one of the important indicators of oil quality. Increase in FFA value leads to formation of off-flavour as a result of degradation of oil. The initial FFA of raw $C$. nigrodigitatus was $1.79 \%$ oleic acid. This value increase significantly $(\mathrm{P}<0.05)$ to $3.16 \%$ oleic acid during smoking process. Iodine value (IV) refers to the percentage of iodine absorbed by a substance such as fat or oil. It measures the amount of double bonds present in the oils and fat, which reflects the susceptibility of the oil or fat to oxidation. The IV of oil extracted from raw and smoked $C$. nigrodigitatus are shown in Table 2. A significant decrease $(\mathrm{P}<0.05)$ in IV was registered in hot smoked $C$. nigrodigitatus compared to raw fish. The presence of unsaturated fatty acids in fish is known to cause rapid oxidation deterioration. Lipids present were oxidized by free radical mechanism producing hydro peroxide. Peroxide value (PV) was used to determine the quality of lipid and it is widely used as indicator for assessment of degree of primary lipid oxidation. The changes of PV during processing are presented in Table 2. The raw fish oil recorded lower PV. However, PV of smoked fish oil has increased significantly $(\mathrm{P}<0.05) . \quad p$-anisidine value measures the aldehyde and ketonic breakdown products of peroxides occurring during lipid oxidation. This, then, is the measure of the materials that give the rancidity to oils and fat (Laguerre et al., 2007). The $p$-anisidine is no detected in raw and smoked $C$. nigrodigitatus.

$P$-anisidine is less specific in determining secondary oxidation of oil and fat. Therefore, $\mathrm{PV}$ and $\mathrm{AV}$ analysis will give better indication of total oxidation as compared to every test individually (Poiana, 2012). The combination of $\mathrm{p}-\mathrm{AV}$ and $\mathrm{PV}$ will indicate lipid quality with more accurate, especially for lipid with low PV (Pingret et al., 2012). The whole stability which relates to lipid deterioration stability will be obtained by measuring of TOTOX value. The finding showed that the TOTOX value in $C$. nigrodigitatus oil samples had an increasing trend (range 7.16 in raw fish to 9.57 in smoked fish). TOTOX value increases with PV in smoked fish oil.

\section{Effect of smoking on fatty acid composition of $C$. nigrodigitatus oil}

The fatty acids profile of raw and smoked $C$. nigrodigitatus oil are presented in Table 3. As shown in Table 3, in raw sample, the most abundant saturated fatty acids (SFAs) observed were palmitic (C16:0) and stearic acid (C18:0). Palmitoleic (C16:1) and oleic acids (C18:1) were the predominant monounsaturated fatty acid (MUFAs). The content of SFAs and MUFAs were the same. Among polyunsaturated fatty acids (PUFAs), linoleic, $\quad \alpha$-linolenic, arachidonic, eicosapentaenoic (EPA) and docosahexaenoic acid (DHA) were most abundant in raw $C$. nigrodigitatus oil. During smoking process, little changes in fatty acid profile were observed in C. nigrodigitatus oil. Smoked fish had low total PUFAs and high total MUFAs when comparing to raw fish. Oleic acid was mostly affected during smoking. Decrease of PUFAs especially linoleic, arachidonic, EPA and DHA were observed during smoking. The PUFA/SFA ratio, which are indexes widely used to evaluate the nutritional value of lipid for human consumption are presented in Table 3. This index decrease during smoking process.

\section{Effect of smoking process on minerals composition $C$. nigrodigitatus}

The mineral contents of raw and smoked C. nigrodigitatus are presented in Table 3. There were significant difference $(\mathrm{P}<0.05)$ in some mineral content between raw and smoked fish in this study. The calcium (Ca) 
content of raw fish was found to be 5170.96 $\mathrm{mg} / 100 \mathrm{~g}$. Ca content of smoked $C$. nigrodigitatus significantly increased $(\mathrm{P}<0.05)$. The magnesium $(\mathrm{Mg})$ content of raw and smoked $C$. nigrodigitatus ranged from $161.95-188.87 \mathrm{mg} / 100 \mathrm{~g}$. The increase in $\mathrm{Mg}$ content after smoking process was found to be significant $(\mathrm{P}<0.05)$. The potassium $(\mathrm{K})$ content of raw and smoke fish ranged from $644-1134 \mathrm{mg} / 100 \mathrm{~g}$. After smoking process, the content of $\mathrm{K}$ duplicate. The sodium $(\mathrm{Na})$ content of C. nigrodigitatus increased from 107 $\mathrm{mg} / 100 \mathrm{~g}$ for raw fish to $130 \mathrm{mg} / 100 \mathrm{~g}$ for smoked fish. Phosphorous is a major constituent of bone together with $\mathrm{Ca}$ and $\mathrm{Mg}$. This mineral showed significant concentration variability between raw and smoked fish in this work. Raw C. nigrodigitatus was found to have higher $\mathrm{P}$ content $(3570 \mathrm{mg} / 100 \mathrm{~g})$ while smoked sample has the lower P content. In the present study the zinc $(\mathrm{Zn})$ and copper $(\mathrm{Cu})$ content of raw fish were $13.67 \mathrm{mg} / 100 \mathrm{~g}$ and
$0.65 \mathrm{mg} 100 \mathrm{~g}$ respectively and were not significant $(\mathrm{P}>0.05)$ affected by smoking process.

The copper $(\mathrm{Cu})$ in this study was found to be the lowest content of trace element. In raw fish, their value was found to be $0.65 \mathrm{mg} / 100 \mathrm{~g}$. The manganese is an important trace mineral involved in the formation of the bones, connective tissues, blood clotting factors and sex hormones. In raw fish their value was 5.01 $\mathrm{mg} / 100 \mathrm{~g}$. This value increased significantly $(\mathrm{P}<0.05)$ in smoked fish. Iron $(\mathrm{Fe})$ is an essential component of the respiratory pigments, haemoglobin, myoglobin and various enzymes system. Its deficiency has been indicated to cause anaemia which is one of the most common nutritional problems worldwide (Batra and Seth, 2002). The mean $\mathrm{Fe}$ content of $C$. nigrodigitatus ranged from $9.28-21.32 \mathrm{mg} / 100 \mathrm{~g}$. The higher Fe content was found in smoked sample.

Table 1: Effect of smoking methods on proximate composition of $C$. nigrodigitatus.

\begin{tabular}{lcccc}
\hline Samples of fish & $\begin{array}{l}\text { Moisture (g/100g } \\
\text { wet weight) }\end{array}$ & $\begin{array}{l}\text { Ash (g/100g } \\
\text { dry weight) }\end{array}$ & $\begin{array}{l}\text { Lipid (g/100g } \\
\text { dry weight) }\end{array}$ & $\begin{array}{l}\text { Protein }(\mathbf{g} / \mathbf{1 0 0 g} \\
\text { dry weight) }\end{array}$ \\
\hline Raw & $72.62 \pm 0.75^{\mathrm{a}}$ & $8.55 \pm 0.66^{\mathrm{b}}$ & $37.48 \pm 0.32^{\mathrm{a}}$ & $51.87 \pm 2.21^{\mathrm{a}}$ \\
Smoke-dried & $18.53 \pm 1.07^{\mathrm{b}}$ & $12.02 \pm 0.17^{\mathrm{a}}$ & $45.94 \pm 1.58^{\mathrm{b}}$ & $44.60 \pm 0.51^{\mathrm{b}}$ \\
\hline
\end{tabular}

Mean values in the same column with different superscript letters are significantly different $(\mathrm{P}<0.05)$.

Table 2: Changes in acid, iodine, peroxide, p-Anisidine and Totox values $C$. nigrodigitatus oil samples during smoking.

\begin{tabular}{llllll}
\hline Samples & $\begin{array}{l}\text { Acid value }(\% \\
\text { oleic acid) }\end{array}$ & $\begin{array}{l}\text { Iodine value }(\mathbf{g} \\
\left.\mathbf{I}_{2} / \mathbf{1 0 0} \mathbf{g} \text { of oil }\right)\end{array}$ & $\begin{array}{l}\text { Peroxide value } \\
\left(\mathbf{m e q} \mathbf{~ O}_{2} / \mathbf{k g} \text { of oil }\right)\end{array}$ & $\begin{array}{l}\text { p-anisidine } \\
\text { value }\end{array}$ & Totox value \\
\hline Raw & $1.79 \pm 0.32^{\mathrm{b}}$ & $80.20 \pm 0.90^{\mathrm{a}}$ & $3.58 \pm 0.03^{\mathrm{b}}$ & nd & $7.16 \pm 0.06^{\mathrm{b}}$ \\
Smoke dried & $3.16 \pm 0.40^{\mathrm{a}}$ & $75.28 \pm 0.22^{\mathrm{b}}$ & $5.01 \pm 0.01^{\mathrm{a}}$ & nd & $9.57 \pm 0.02^{\mathrm{a}}$ \\
\hline
\end{tabular}

Mean values in the same column with different superscript letters are significantly different $(\mathrm{P}<0.05)$; nd: not detected. 
Tableau 3: Changes in fatty acid composition of $C$. nigrodigitatus oil after smoking process.

\begin{tabular}{lll}
\hline Fatty acid as \% of total fatty acids & Raw & Smoke dried \\
\hline C10:0, Capric & $0.07 \pm 0.01^{\mathrm{a}}$ & $0.10 \pm 0.01^{\mathrm{a}}$ \\
C12 :0, Lauric & $1.21 \pm 0.14^{\mathrm{b}}$ & $0.75 \pm 0.05^{\mathrm{a}}$ \\
C14.0, Myristic & $2.38 \pm 0.02^{\mathrm{b}}$ & $2.84 \pm 0.07^{\mathrm{a}}$ \\
C15 :0, Pentadecanoic & $0.96 \pm 0.05^{\mathrm{a}}$ & $1.00 \pm 0.02^{\mathrm{a}}$ \\
C16 :0, Palmitic & $21.80 \pm 0.07^{\mathrm{b}}$ & $23.47 \pm 0.08^{\mathrm{a}}$ \\
C17 :0, Heptadecanoic & $2.10 \pm 0.00^{\mathrm{b}}$ & $2.44 \pm 0.06^{\mathrm{a}}$ \\
C18 :0, Stearic & $9.96 \pm 0.03^{\mathrm{a}}$ & $10.04 \pm 0.10^{\mathrm{a}}$ \\
C20 :0, Arachidique & $1.82 \pm 0.05^{\mathrm{a}}$ & $0.76 \pm 0.02^{\mathrm{b}}$ \\
C22 :0, Behenic & $0.40 \pm 0.01^{\mathrm{a}}$ & $0.38 \pm 0.03^{\mathrm{a}}$ \\
C23 :0, Tricosanoic & $0.42 \pm 0.03^{\mathrm{a}}$ & $0.45 \pm 0.01^{\mathrm{a}}$ \\
C24 :0, Lignoceric & $0.11 \pm 0.00^{\mathrm{a}}$ & $0.14 \pm 0.03^{\mathrm{a}}$ \\
$\Sigma$ SFA & $41.25 \pm 0.45^{\mathrm{a}}$ & $39.93 \pm 0.49^{\mathrm{a}}$ \\
C16 :1, Palmitoleic & $6.35 \pm 0.02^{\mathrm{b}}$ & $7.96 \pm 0.08^{\mathrm{a}}$ \\
C17 :1n Cis-10 heptadecenoic & $1.34 \pm 0.00^{\mathrm{a}}$ & $1.10 \pm 0.01^{\mathrm{b}}$ \\
C18 :1(n-9), Oleic & $30.77 \pm 0.50^{\mathrm{b}}$ & $34.08 \pm 0.31^{\mathrm{a}}$ \\
C20 :1, cis-11 Eicosenoic & $1.99 \pm 0.11^{\mathrm{a}}$ & $1.47 \pm 0.02^{\mathrm{b}}$ \\
C22 :1, Erucic & $0.22 \pm 0.01^{\mathrm{b}}$ & $0.99 \pm 0.03^{\mathrm{a}}$ \\
$\Sigma$ MUFA & $40.67 \pm 0.64^{\mathrm{b}}$ & $45.60 \pm 0.45^{\mathrm{a}}$ \\
C8 :2, Linoleic $(\omega-6)$ & $4.62 \pm 0.02^{\mathrm{a}}$ & $3.19 \pm 0.05^{\mathrm{b}}$ \\
C18 :3, -linoleic $(\omega-6)$ & $0.15 \pm 0.00^{\mathrm{a}}$ & $0.10 \pm 0.00^{\mathrm{b}}$ \\
C18 :3, $\alpha-$ linoleic $(\omega-3)$ & $1.71 \pm 0.06^{\mathrm{a}}$ & $1.13 \pm 0.27^{\mathrm{a}}$ \\
C20 :2, cis 11, 14 Eicosadienoic & $0.75 \pm 0.08^{\mathrm{b}}$ & $1.03 \pm 0.02^{\mathrm{a}}$ \\
C20 :3, cis-8, 11, 14 Eicosatrienoic $(\omega-6)$ & $1.26 \pm 0.10^{\mathrm{a}}$ & $0.77 \pm 0.04^{\mathrm{b}}$ \\
C 20 :4, Arachidonic $(\omega-6)$ & $2.89 \pm 0.20^{\mathrm{a}}$ & $1.99 \pm 0.13^{\mathrm{b}}$ \\
C20 :5, Eicosapentaenoic $($ EPA) $(\omega-3)$ & $3.76 \pm 0.01^{\mathrm{a}}$ & $2.35 \pm 0.05^{\mathrm{b}}$ \\
C22 :6, Docosahexaenoic $(D H A)(\omega-3)$ & $1.88 \pm 0.09^{\mathrm{a}}$ & $0.94 \pm 0.01^{\mathrm{b}}$ \\
$\Sigma$ PUFA & $17.33 \pm 0.56^{\mathrm{a}}$ & $11.50 \pm 0.65^{\mathrm{b}}$ \\
$\Sigma \omega-3$ PUFA & 7.30 & 4.42 \\
$\Sigma \omega-6$ PUFA & 9.67 & 7.06 \\
$\omega-6: \omega-3$ & 1.32 & 1.60 \\
PUFA/SFA & 0.42 & 0.29 \\
\hline & D & \\
\hline
\end{tabular}

Mean values in the same line with different superscript letters are significantly different $(\mathrm{P}<0.05)$.

Table 6: Effect of dried methods on mineral composition of the three fish species (mg/100g).

\begin{tabular}{llllllllll}
\hline Samples of fish Ca & Mg & K & Na & P & Zn & Cu & Mn & Fe \\
\hline Raw & $5170.96 \pm 21.00^{\mathrm{b}}$ & $161.95 \pm 2.00^{\mathrm{b}}$ & $644.05 \pm 17.00^{\mathrm{b}}$ & $107.88 \pm 5.25^{\mathrm{b}}$ & $3570.02 \pm 31.00^{\mathrm{a}}$ & $13.67 \pm 0.45^{\mathrm{a}}$ & $0.65 \pm 0.01^{\mathrm{a}}$ & $5.01 \pm 0.04^{\mathrm{b}}$ & $9.28 \pm 1.00^{\mathrm{b}}$ \\
Smoke-dried & $8730.33 \pm 15.00^{\mathrm{a}}$ & $188.87 \pm 5.00^{\mathrm{a}}$ & $1134.71 \pm 14.00^{\mathrm{a}}$ & $130.92 \pm 3.01^{\mathrm{a}}$ & $2603.75 \pm 10.00^{\mathrm{b}}$ & $10.08 \pm 1.88^{\mathrm{a}}$ & $0.77 \pm 0.02^{\mathrm{a}}$ & $6.67 \pm 0.01^{\mathrm{a}}$ & $21.32 \pm 1.32^{\mathrm{a}}$ \\
\hline
\end{tabular}

Mean values in the same column with different superscript letters are significantly different $(\mathrm{P}<0.05)$. 


\section{DISCUSSION}

The biochemical composition of raw fish noted in this study are similar to those obtained by others authors for the same species (Tenyang et al., 2016; Djopnang et al., 2018). The moisture content of smoked fish noted in this work is higher than those obtained by Djopnang et al. (2018) (15.89\%) for smoked Chrysichthys nigrodigitatus collected in Nkam river. Decrease of moisture content occurring during smoking is the consequence of water loss during this process. The same trends were noted by Adeyemi et al. (2013) on Trachurus trachurus, a fish commonly consumed in Nigeria during drying process. Moisture is a parameter which determines the qualities of dried fish products. It has been noted that fish with $25 \%$ or more moisture is not sufficient to inhibit microbial growth like mould. Whereas, dried fish with $15 \%$ or less moisture is well enough to inhibit the growth of microbes (Immaculate et al., 2012). It can be seen in this work that moisture content of smoked Chrysichthys nigrodigitatus was less than $20 \%$. Variation in ash content noted in this work is in agreement with the finding of Fapohunda and Ogunkoya (2006) in some water fish in Nigeria. Increase in the ash content in smoked fish can be due to the significant reduction in the moisture content occurring during smoking process. Determination of ash content indicates largely the mineral content present in fish. Lipid content of raw $C$. nigrodigitatus is higher compared to those noted by Tenyang et al. (2016) (30\%) in the same species. Variation can be due to the season, ages, natural status and physiological status. According to the lipid content noted in this work, $C$. nigrodigitatus can be ranged into fatty fish. After smoking process, increase in lipid content observed could be the result of moisture evaporation (Eyo, 2001). The protein content of $C$. nigrodigitatus in this study decreases significantly during processing. These observations are in discordance with the finding of Mossarat et al. (2016) when evaluated the effect of smoking of some
Bangladesh fishes and Akinneye et al. (2007) when evaluated the effect of dying methods on the nutritional composition of three fish species in Nigeria. The lower protein content noted in smoked fish could be linked to denaturation of initial protein in fish during smoking. Decrease in protein content observed during smoking is also due to unavailable of lysine which usually varies from $6-33 \%$ at $25{ }^{\circ} \mathrm{C}$ to $53-56 \%$ during hot smoking. Reduction in lysine is directly proportional to the temperature and smoking duration.

Concerning the oil qualities parameters, the FFA of raw fish oil obtained in this study is very low compared to that obtained by Djopnang et al. (2018) with the same species ( $10.25 \%$ oleic acid). The difference could be due to the technique of extraction of lipid. Increase in FFA recorded during smoking may be attributed to thermal lipolysis of triglycerides due to relatively high temperature $\left(\sim 70{ }^{\circ} \mathrm{C}\right)$. Increases in FFAs during smoking is an agreement with the results reported by Tenyang et al. (2017) who observed increase in FFA of raw herring after smoking. Tenyang et al. (2020) also reported that FFA has become unacceptable only when their value exceeds the acceptable limit of 5\% oleic acid in fish. In this study, the FFA value of smoked $C$. nigrodigitatus is less than $5 \%$ oleic acid. The low value of FFA obtained indicates a good quality of this fish product. As shown in Table 2 , decrease in IV during smoking process are not in the line with the finding of Djopnang et al. (2018) who noted no significant variation between raw and smoked $C$. nigrodigitatus collected in littoral region. However, these observations are in agreement with the results mentioned by Tenyang et al. (2017), who demonstrated that smoking process decrease IV of smoked herring oil. The lower IV noted in smoked sample indicates that, the double bonds of unsaturated fatty acid of $C$. nigrodigitatus are oxidized during smoking. Triglyceride and phospholipids present in fish oil underwent to thermal hydrolysis into free fatty acids. Free polyunsaturated and 
monounsaturated fatty acid possibly undergo oxidation. A decrease in IV observed during smoking also indicates an increase in the degree of saturation of fatty acids which is a risk factor for hypercholesterolemia and some types of cardiovascular diseases (Tenyang et al., 2017). A significant increase $(\mathrm{P}<0.05)$ of PV observed in this study during smoking might be a result of formation and accumulation of hydroperoxide induced by heating. It may be caused by interaction of free radical with oxygen molecular during processing. Tenyang et al. (2017) when evaluated the effect of smoking on lipid oxidation of herring fish noted the same trend. The PV of smoked $C$. nigrodigitatus oil is below $10 \mathrm{meq} / \mathrm{kg}$, a standard specified by FAO/WHO (2009) for fresh edible oil. In this study, TOTOX value increase with processing and De Abreu et al. (2010) reported that the recommended standard TOTOX value is less or equal to $19.5 \mathrm{meq} / \mathrm{kg}$. The TOTOX value obtained in smoked $C$. nigrodigitatus oil is the half of recommended value, this suggest the good quality of smoked fish oil.

In general, twenty four fatty acids were identified in $C$. nigrodigitatus. The total PUFAs mentioned in this study were much lower than that of SFAs and MUFAs. Among saturated and monounsaturated fatty acids present in raw fish, the highest was C18:1, followed by $\mathrm{C} 16: 1$ and C18:0. These observations are different with the findings of Djopnang et al. (2018) for the same species. Oleic acid (C18:1) which is very high in $C$. nigrodigitatus oil has exogenous origin and reflect the type of diet consumed by fish. Arachidonic acid present in the fish oil may play many important roles in human. They are a precursor of prostaglandin and thromboxane biosynthesis. They can facilitate the blood clotting process (Pompeia et al., 2002). Inclusion of $C$. nigrodigitatus in human diets might help in wound healing process of the consumers. Tenyang et al. (2016) have shown that freshwater fish had lower omega-3 PUFAs, which is in line with the present findings. C. nigrodigitatus can be used to supplement essential fatty acids in the diet of human. EPA and DHA have been recognized as beneficial for human health by reducing the risk of cardiovascular diseases and artery coronary. DHA is essential for the development of the foetal brain and the eye retina (Calder, 2006). A smoking method used showed a significant change in fatty acid composition and this is in agreement with the results reported by Djopnang et al. (2018). The proportion of PUFAs was decreased significantly $(\mathrm{P}<0.05)$ in smoked fish, like in the investigation of Tenyang et al. (2020) comparing in raw fish. Decrease in PUFAs during smoking may be explained by the susceptibility of unsaturated fatty acids to oxidation. During processing, fish oil can undergo several reactions such as hydrolysis and oxidation. This was evidence by increase of PV and decrease of IV in smoked $C$. nigrodigitatus oil. These reactions may affect the nutritional value of fish. As an important nutritional index of fatty acid, PUFA/SFA ratio in human diet should be above 0.45 (Wood et al., 2008). In the present study, smoked sample showed lower ratio with value under the recommendation limit.

Smoked fish are popular processed food in many countries in Africa. They are played important role in the physicochemical properties of fish product. Raw fish presented high calcium and phosphorus. The $\mathrm{Ca}$ content of raw fish was found to be higher than those noted by Obadai et al. (2009) for other fish species. Difference observed could be due to their concentration in the water and the ability of fish to absorb the element from their diets and water (Adewumi et al., 2014). Increase in Ca content in smoked fish noted in this study is in disagreement with the finding of Djopnang et al. (2018) who reported no significant difference between the $\mathrm{Ca}$ of raw and smoked fish. The recommendation daily allowance (RDA) intake of Ca for adult is $1000-1300 \mathrm{mg}$ (FAO/WHO, 2001). Regular consumption of about $15 \mathrm{~g}$ portion of smoked fish will cover 
$100 \%$ RDA. This will provide good bone formation and maintain integrity of skeletal of consumers. $\mathrm{Mg}$ is an essential cofactor for multiple enzymes involved in the glucose metabolism and it is hypothesized to play a prominent role in glucose homeostasis (Murray et al., 2000). Although, deficiency of $\mathrm{Mg}$ is not very common but is likely to occur in association with alcoholism, kidney and gastro intestinal diseases. The $\mathrm{Mg}$ content of raw fish obtained in this study is lower compared to the value mentioned by Beyza and Akif (2009) with African catfish (182 mg/100g). Smoked fish compared to raw fish in this work had the high Mg content. Djopnang et al. (2018) have also shown that smoked $C$. nigrodigitatus has higher $\mathrm{Mg}$ content. The increase observed in the $\mathrm{Mg}$ content in the smoked fish could be attributed to the loss of moisture and an increase in the dry matter during processing. The RDA intake of Mg for adult is $220-260 \mathrm{mg}$ per day (FAO/WHO, 2001), and $138 \mathrm{~g}$ of smoked fish can contributed $100 \%$ of this requirement.

$\mathrm{K}$ is an essential element in the body system that plays a vital role in protein synthesis, nerve conduction, control of heart beat, muscle contraction and synthesis of nucleic acid. However, deficiency of this element could result to tiredness and muscle weakness (Saoetan et al., 2010). The significant increase in the $\mathrm{K}$ content during smoking is an accordance with the report of Akenneye et al. (2007) in smoked Bonga sp, Sardinella sp and Heterotis niloticus. The RDA of $\mathrm{K}$ for males aged between 25-50 years is 800 mg per day. Regular consumption of about 70 $\mathrm{g}$ of smoked $C$. nigrodigitatus will provide $100 \%$ of $\mathrm{K}$ daily requirement. Na which is an important element to human life plays a significant role in the blood plasma and normal functioning to the nervous systems. Due to their high content in smoked fish, the consumption of smoked $C$. nigrodigitatus could be useful as a supplement for human benefit.
$\mathrm{P}$ content of raw $C$. nigrodigitatus noted in this study is higher than the values reported to other freshwater fish by Alas et al. (2014). The RDA of $\mathrm{P}$ for adult is $700 \mathrm{mg}$ per day (FAO/WHO, 2001). Consumption of $24 \mathrm{~g}$ portion of smoked fish can contributed at $100 \%$ of the daily requirement. $\mathrm{Zn}$ is a component of many metalloenzymes, participating in the synthesis and degradation of carbohydrates, lipids, proteins, and nucleic acid. Zn stabilizes the molecular structure of cellular components and membranes. For adult, their RDA is $8-11$ mg. Consumption of $100 \mathrm{~g}$ portion of smoked fish can provide $100 \%$ of this requirement. The $\mathrm{Cu}$ content of raw fish is higher than that reported by Beyza and Akif (2009) for African catfish $(0.2 \mathrm{mg} / 100 \mathrm{~g})$. No significant $(\mathrm{P}<0.05)$ variation in $\mathrm{Cu}$ content was also observed by the same author for African catfish. Increase in Mn content during smoking observed in this study is in accordance with the results mentioned by Beyza and Akif (2009) and may be due to dehydration occurred during processing. The RDA of Mn for adult is 2-5 mg. If consumers take about $72 \mathrm{~g}$ of smoked $C$. nigrodigitatus, they would cover $100 \%$ of the requirement.

The Fe content of raw fish in this study is high compared to those reported by Djopnang et al. (2018) for the same species. Akinwumi (2014) reported that Fe content of Clarias gariepinus increased significantly $(\mathrm{P}<0.05)$ during smoking process. This observation is in agreement with the results noted in this work. The RDA of Fe is $8-18 \mathrm{mg}$. Regular consumption of smoked fish, about 80 $\mathrm{g}$ will cover $100 \%$ of the requirement.

\section{Conclusion}

The effect of local smoking on proximate composition, oil qualities and mineral contents of $C$. nigrodigitatus was examined. It was found that local smoking had important effect on nutritional value fish. Smoked fish presented high ash and lipid contents. The lower protein content was obtained with smoked fish. An increase of 
lipolysis during processing indicated by high FFAs content in smoked fish oil. During smoking, unsaturated fatty acids of fish lipid underwent oxidation. This is justified by the high concentration of PV and the decrease of iodine value. The marked decrease of PUFAs especially arachidonic acid, EPA and DHA were noted during processing. $\mathrm{Ca}, \mathrm{Mg}, \mathrm{K}, \mathrm{Na}$, $\mathrm{Mn}$ and Fe contents of smoked fish increased, while $\mathrm{P}$ contents decrease after smoking process. However, the change in $\mathrm{Zn}$ and $\mathrm{Cu}$ content were found to be no significant in smoked fish.

\section{COMPETING INTERESTS}

The authors declare that they have no competing interests.

\section{AUTHORS' CONTRIBUTIONS}

NT conceived and designed the experiments; performed the experiments, analyzed and interpreted the data, contributed reagents, materials, wrote the paper. RP performed the experiments, analyzed and interpreted the data, contributed reagents. HMW Analyzed and interpreted the data, wrote the paper.

\section{ACKNOWLEDGEMENTS}

We thank the head of Laboratory of Bioscience of the National Advanced School of Engineering of Maroua for technical assistance.

\section{REFERENCES}

Abolagba OJ, Osifo SJ. 2008. The effect of smoking on the chemical composition and keeping qualities of catfish (Heterobrancus bidorsalis) using two energy sources. J.A.F.F., 5(1): 27-30.

Adewumi AA, Adewole HA, Olaleye WRL. 2014. Proximate and elemental composition of the fillets of some fish species in Osinmo Reservoir, Nigeria. Agric. Biol. J. N. Am., 5: 109-117. DOI:10.5251/abjna.2014.5.3.109.117
Adeyemi OT, Osilesi OO, Onajobi F, Adebawo O, oyedemi SO, Afolayan J. 2013. Effect of processing on the proximate and mineral compositions of Trachurus trachurus: A fish commonly consumed in Nigeria. J.E.T.E.A.S, 4(3): 378-385.

Adeyeye SAO, Oyewole OB, Obadina AO, Omemu AM. 2015. Influence of smoking method on quality of traditional smoked Bonga shad (Ethnalosa frimbriata) fish from Lagos State, Nigeria. Afric. J. Food Sci., 9(4): 200-207. DOI : 10.5897/AJFS2014.1250.

AFNOR. 1981. Recueil des Normes Françaises. Corps Gras, Graines Oléagineuses, Produit Dérivés $\left(^{\text {nd }}\right.$ Édition). AFNOR : Paris.

Akinneye JO, Amoo IA, Arannilewa ST. 2007. Effect of drying methods on the nutritional composition of three species of fish (Bonga sp. Sardinella sp. and Heterotis niloticus). J. Fish. Int., 2(1): 99103. DOI=Jfish.2007.99.103

Akinwumi FO. 2014. Effects of smoking and freezing on nutritive value of African Mud catfish, Clarias gariepinus (Burchell, 1822). J. Agric. Sci, 6(11): 143-149. DOI: 10.5539/jas.v6n11p143

Alas A, Ozcan MM, Harmankaya M. 2014. Mineral contents of head, caudal, central fleshy part, and spinal columns of some fishes. Environ. Monit. Assess, 186: 889894. DOI: 10.1007/s10661-013-3429-3.

Ali A, Ahmadou D, Mohamadou BA, Saidou C, Tenin D. 2011. Influence of traditional drying and smoke drying on quality of three fish species (Tilapia niloticus, Silurus glanis and arius parkii) from Lake Lagdo, Cameroon. J. Anim. Vet. Advan., 10(3): 301-306. DOI: 10.3923/javaa.2011.301.306.

Al-Jedah JH, Robinson RK. 2001. Aspects of the safety of the fish caught off the coast of Qatar. Food Control, 12: 549-552. DOI: 10.1016/S0956-7135(01)00070-6 
AOAC. 1990. Official Methods of Analysis (16th edn). Association of Official Analytical Chemists: Washington, DC.

AOAC. 1999. Official Methods of Analysis (21st edn). Association of official analytical chemists: Washington, DC, USA.

Batra J, Seth PK. 2002. Effect of iron deficiency on developing rat brain. Indian J. Clin. Biochem., 17(2): 108-114. DOI: 10.1007/BF02867982.

Beyza E, Akif O. 2009. The effect of cooking methods on mineral and vitamin contents of African catfish. Food Chem., 115: 419422.

DOI:

10.1016/j.foodchem.2008.12.018

Bhandari S, Banjara MR. 2014. Micronutrients deficiency, a hidden hunger in Nepal: prevalence, causes, consequences and solutions. Int. Sch. Res. Notices, 1-9.

Bligh EC, Dyer WJ. 1959. A rapid method of total lipid extraction and purification. Can. J. Biochem. Physiol., 37: 911-917.

Calder CP. 2006. Polyunsaturated fatty acids, inflammation, and inflammatory diseases. Am. J. Clin. Nutr., 83: 1505s1519s., DOI: 10.1093/ajen/83.6.1505S.

De Abreu DP, Losada PP, Maroto J, Cruz J. 2010. Evaluation of the effectiveness of a new active packaging film containing natural antioxidants (from barley husks) that retard lipid damage in frozen atlantic salmon (salmo salar L.). Food Res. Int., 43(5): $\quad$ 1277-1282. DOI: 10.1016/j.foodres.2010.03.019

Djopnang DJ, Tchoumbougnant F, Tomedi TEM, Womeni HM, Tonfack DF, Prabhakar INS, Karuna MSL, Prasad RBN, Kemmo SS, Gouado I. 2018. Effects of boiling and smoking on proximate composition and oil quality of commercially important freshwater fish (Chrysichthys nigrodigitatus) from Nkam river in Cameroon. J. Food Res., 7(6): 5969. DOI: $10.5539 /$ jfr.v7n6p59.

Eyo AA. 2001. Fish processing technology in the Tropics. A Publication of National
Institute for Freshwater Fisheries Research (NIFFR), PMB6006, New Bussa, Nigeria.

FAO. 2010. The state of food insecurity in world. Addressing food insecurity in protracted crisis, Rome, Italy.

FAO/WHO. 2001. Human vitamin and mineral requirements, Rome: FAO.

FAO/WHO. 2009. Report of the $21^{\text {st }}$ session of the Codex Alimentarius Committee on fats and Oils. Kola Kinabala, Malaysia, 16-20 February 2009.

Fapohunda OO, Ogunkoya O. 2006. Effect of smoke drying on the proximate composition of Tilapia zili, Parachanna obscura and Clarias gariepinus obtained from Akure, Ondo-State, Nigeria. Anim. Res. Int., 3(2): 478-480.

Goulas AE, Kontominas MC. 2005. Effects of salting and smoking method on the keeping quality of chub mackerel (Scomber japonicas): biochemical and sensory attributes. Food Chem., 93: 511520.

Immaculate J, Sinduja P, Jamila P. 2012. Biochemical and microbial qualities of sardinella fimbriata sundried in different methods. Int. Food Res. J., 19(4): 16991703.

Khaoula T, Tarek H, Imen R, M'hqmed El Cafsi. 2013. The changes of fatty acid composition in sun dried, oven dried and frozen hake (Merluccius merliccius) and sardinella (Sardinella aurita). Afr. J. Biochem. Res., 7(8): 158-164. DOI: 10.5897/AJBR2013.0707.

Laguerre M, Lecomte J, Villeneuve P. 2007. Evaluation of the ability of antioxidants to counteract lipid oxidation: Existing methods, new trends and challenges. Lipid Res., 46: 244-282.

Metcalfe LD, Schmitz AA, Pelka JR. 1966. BF3-methanol procedure for rapid quantitative preparation of methyl esters from lipids. Anal. Chem., 38: 514.

Mossarat NN, Gulshan AL, Subhash CC, Farzana BF, Mohajira B. 2016. Shelf-life 
quality of smoke dried freshwater SIS fish: Chapila (Gudusia chapra, Hamiltonbuchanan; 1822), Kaika (Xenentodon cancila, Hamilton-buchanan; 1822) and Baim (mastacembelus pancalus, Hamilton-buchanan; 1822). IOSR J.A.V.S., 9(3): 23-32.

Njinkoué JM, Manzkoule JC, Tchoumbougnang F, Milong Melong CS, Tchintchui NC, Fowe CR, Schweigert FJ, Gouado I. 2017. Evaluation des effets hypolipidemiants de l'huile extraite du poisson pseudotolithus senegalensis chez des rates ayant subi une dislipidemie. Int. J. Biol. Chem. Sci., 11(6): 2952-2961. DOI:

https://dx.doi.org/10.4314/ijbcs.v11i6.31

Obodai EA, Abbey LD, MacCarthy C. 2009. Biochemical composition of some marine fish species of Ghana. Int. J. Biol. Chem. Sci., 3(2): 406-409. DOI: 10.4314/ijbcs.v3i2.44499.

O'keefe SF, Pike OA. 2010. Fat characterization In Food Analysis $\left(4^{\text {th }}\right.$ edn), Nielsen SS (Ed). Springer Science and Business Media: New York, NY, USA; 239-260.

Pingret D, Durand G, Fabiano-Tixier A, Rockenbauer A, Ginies C, Chemat F. 2012. Degradation of edible oil during food processing by ultrasound, electron paramagnetic resonance, physiochemical, and sensory appreciation. J. Agric. Food Chem., 60(31): 7761-7768. DOI: 10.1021/Jf301286f

Poiana MA. 2012. Enhancing oxidative stability of sunflower oil during convective and microwave heating using grape seed extract. Int. J. Mol., 13(7): 9240-9259. DOI: 10.3390/ijms 13079240

Saoetan KO, Olaiya CO, Oyewole OE. 2010. The importance of mineral elements for humans, domestic animals and plant: A Review. Afr. J. Food Sci., 4(5): 200-222.

Shahidi F, Wanasundara UN. 2008. Methods for measuring oxidative stability in edible oils. In Food Lipids: Chemistry, Nutrition and Biotechnology, Akoh CC, Min DB (eds). CRC Press: New York, 387-388.

Shantha NC, Decker EA. 1994. Rapid, sensitive, iron-based spectrophotometric methods for determination of peroxide values of food lipids. J. AOAC Int., 77 (2): 421-424.

Tacon AGJ, Metian M. 2009. Fishing for feed or fishing for food: Increasing global competition for small pelagic forage fish. Ambio, 38(6): 294-302.

Tenyang N, Ponka R, Tiencheu B, Tonfack DF, Womeni HM. 2016. Proximate composition, fatty acid and mineral contents of four fish from Lake Maga (Far North Region of Cameroon). Am. J. Food Technol., 4(3): 64-69. DOI: 10.12691/ajfst-4-3-2.

Tenyang N, Tiencheu B, Womeni HM. 2017. Effect of smoking and refrigeration on lipid oxidation of Clupea harengus: A fish commonly consumed in Cameroon. Food Sci. Nutr., 1-10. DOI: https://doi.org/10.1002/fn3.575.

Tenyang N, Ponka R, Tiencheu B, Tonfak DF, Womeni HM. 2020. Effect of traditional drying methods on proximate composition, fatty acid profile, and oil oxidation of fish species consumed in the Far-North of Cameroon. Global Challenge, 2000007 (1-8). DOI: $10.1002 /$ gch 2.202000007 .

Wood D, Enser M, Fisher AV, Nute GR, Sheard PR, Richardson RI, Hughes SI, Whittington FM. 2008. Fat deposition, fatty acid composition and meat quality: A Review. Meat Sci., 78: 343-358. DOI: 10.1016/j.meatsci.2007.07.019. 